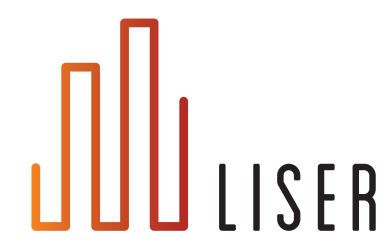

LUXEMBOURG InSIITUTE OF SOCIO-ECONOMIC RESEARCH

Making the switch from joint to

individual taxation in Luxembourg.

Cost, behavioural response and welfare effects

\author{
Nizamul ISLAM ${ }^{\mathbf{1}}$ \\ Karina DOORLEY 2, 3,4 \\ Lennart FLOOD ${ }^{5}$
}

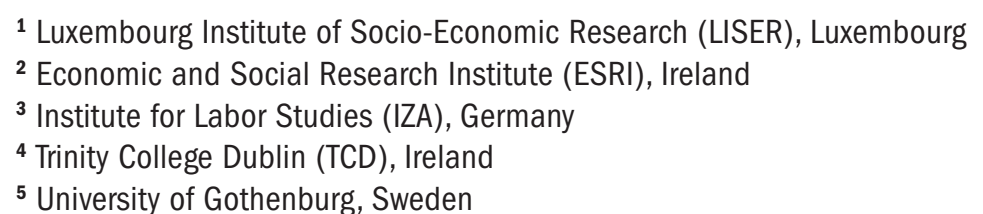


LISER Working Papers are intended to make research findings available and stimulate comments and discussion. They have been approved for circulation but are to be considered preliminary. They have not been edited and have not been subject to any peer review.

The views expressed in this paper are those of the author(s) and do not necessarily reflect views of LISER. Errors and omissions are the sole responsibility of the author(s). 


\title{
Making the switch from joint to individual taxation in Luxembourg. Cost, behavioural response and welfare effects.
}

\author{
NIZAMUL ISLAM K KARINA DOORLEY $\wedge$ LENNART FLOOD^
}

\begin{abstract}
:
We study the effect of a move from joint to individual taxation system using 2,276 couple household living in Luxembourg. We estimate simultaneously labour supply and social assistance (RMG) participation, exploiting a discrete choice model. We focus on the distributional, work (extensive and intensive margin) incentive, and the social welfare effect of introducing a mandatory individual taxation system in Luxembourg. The work incentive of married women increases by $2.27 \%$ in intensive margin and $2.58 \%$ in extensive margin after the reform. The incentive of married men is almost zero. Equivalised disposable income, after the behavioural adjustment, decreases on average 2.1 per cent. After adjustments to direct and indirect taxes, the net revenue-neutral result is a budget surplus for the central government of around $€ 10$ million.
\end{abstract}

Key words: Microsimulation, Labour supply, Joint taxation, Welfare

JEL classification numbers: B21, B31, D31, H24, H31

\footnotetext{
-Nizamul Islam is affiliated to the Luxembourg Institute of Socio-Economic Research (LISER). E-mail: nizamul.islam@liser.lu. The authors are grateful to Eugenio Peluso LISER Luxembourg, and other anonymous referees for their valuable comments.

^Karina Doorley is affiliated to the Economic and Social Research Institute (ESRI), Institute for Labor Studies (IZA) and Trinity College Dublin (TCD). E-mail: karina.doorley@esri.ie

"Lennart Flood is affiliated to the Department of economics, University of Gothenburg. E-mail: Lennart.Flood@handels.gu.se.
} 


\section{Introduction}

Since January 2018, members of a couple can elect to be taxed individually in Luxembourg. Under individual taxation, each spouse's labour income is taxed independently from the other spouse, meaning that two households with the same household income might face different income tax schedules. Thus, a move from joint to individual taxation can change net household income. The focus of this paper is the consequence of mandatory individual taxation, which is still under discussion in Luxembourg.

Over the last few decades, the general trend in European Union countries has been a move from joint towards individual taxation. However, joint taxation, whereby the income of a couple in a household is fully split between them or aggregated in determining the income tax liability, is still present in some EU countries, such as Luxembourg, France and Portugal, despite the fact that this system imposes higher marginal tax rates for the secondary earner in the couple (Blundell and Macurdy, 1999). As women are generally the secondary earners in a couple household and as they typically have more elastic labour supply, theory predicts that the optimal taxation model for labour supply should not impose higher marginal tax rates on women. Recent work by Bick and Fuchs-Schündeln (2017), which studies the US and 17 EU countries, finds large disincentive effects of joint taxation on the hours worked of married women. A shift, therefore, from joint to individual taxation, which would equalize the marginal tax rates of the primary and secondary earner, is worth considering from the perspective of increasing female labour supply. It is a policy measure which could also decrease the administrative burden of the tax authorities, given that modern couples are less likely to marry and more likely to separate than the previous generation.

Previous empirical research has evaluated the labour market effect of hypothetical shifts from joint to individual taxation. In Germany, the participation rate of married women can be expected to increase by up to $6 \%$ (Decoster and Haan, 2014). In a comparison of cohabiting and married couples in France, Kabatek et al. (2014) show that switching to an individual system of taxation would increase female labour supply by $3.7 \%$ and decrease male labour supply by $0.8 \%$. Evaluating the opposite reform for Italy, Colonna and Marcassa (2015) study the effect of a hypothetical shift from individual to joint taxation and find a labour supply response of 5-6 ppt. There have also been studies which have evaluated the incentive effects of individual taxation in a natural experiment framework. LaLumia (2008) shows that the labour 
supply of married women decreased by 2ppt after the shift from individual to joint taxation in the US in 1948. Kaliskova (2014) also found that switching from individual to joint taxation in Czech Republic in 2005 lead to a decline in the employment rate of married women with children of about 3 percentage points. Between 1969 and 1975, a 10 ppt increase in the labour force participation of married women in Sweden has been attributed to the introduction of individual taxation in 1971 (Selin 2014). A reform which partly individualized the Irish taxation system increased the participation rate of married women by around $5 \mathrm{ppt}$ (Doorley, 2018). Finally, using a fiscal reform from 1988, which abolished one of the last "joint" features of the Canadian system, Crossley and Jeon (2007) find an increase in the labour supply of low educated women of around 10 ppt. This paper builds on these findings.

We use a discrete choice labor supply model to assess the effects of a transition from joint to individual taxation. We focus on the distributional, labour supply, and the social welfare effect of introducing a mandatory individual taxation system in Luxembourg. We assume that household utility depends not simply on income and leisure, but also on participation in the Social Assistance / Guaranteed Minimum Income (RMG) scheme. We estimate simultaneously labour supply model and the Guaranteed Minimum Income (RMG)/Social Assistance receipt taking into account the joint decision of couple labour supply and RMG participation. This approach offers an alternative way to examine the welfare implications of switching to individual taxation. That means that the correct model is not a two-dimensional model, labor time/consumption, but a three-dimensional one in which the third dimension is a zero-one dimension about the willingness to participate RMG scheme when they are available. We find that labour supply of married women increases by around $2.27 \%$ after the reform. There is no effect on the labour supply of married men. Equivalised disposable income, after the behavioural adjustment, decreases on average 2.1 per cent. After adjustments to direct and indirect taxes, the net revenue-neutral result is a budget surplus for the central government of around $€ 10$ million. The major share of RMG recipient-households have strong preferences for leisure over work.

The next section describes the institutional background. Section 3 briefly summarize the EUSILC data that have been used for labour supply model. The estimated model is presented in section 4 , together with the model prediction and labour supply elasticity. Section 5 discuss the simulation results of the reform. Section 6 summarizes the main findings of the paper. 


\section{The institutional background}

\subsection{The income tax system in Luxembourg}

The Grand-Duchy of Luxembourg, along with the Netherlands, Belgium, Germany and France belongs to the "Continental Welfare State" model. This type of model has some similarities with the Nordic model which is based on the principle of security and a system of subsidies which are independent of work. Luxembourg's household taxable income is composed of employment and self-employment income, investment and rental income, pensions and annuities, and various other income (such as capital income). Total taxable household income is defined as the sum of the partners' earnings to which their unemployment benefits, social assistance, and housing benefits are added. After income tax deduction and social security contributions, the net household income is obtained.

In Luxembourg, personal income tax, l'impôt sur le revenu des personnes physiques, is currently imposed at the level of the family unit where the family unit is defined by marriage or civil partnership. Taxpayers are accorded a tax class according to their family status. Married taxpayers belong to tax class 2 as do civil partners who live together for a full tax year and elect to file jointly or separately. Most other individuals belong to tax class 1 (except for the elderly, single parents and some widow(er)s).

The tax schedule is progressive. Table 1 shows the tax schedule applied to taxpayers in tax class 1 in 2009 (the year used in our simulations). ${ }^{1}$ For taxpayers in tax class 2 , tax is determined by applying the tax schedule to household-taxable income, divided by two. The tax bill obtained is then multiplied by two. A form of "marriage premium" called an abattement extra-professionnel also exists, consisting of a tax-free allowance of EUR 4,500 per annum awarded to married couples in which both spouses work. There are three refundable tax credits, one for employees, one for pensioners and one for single parents. These are all awarded at the individual level.

\footnotetext{
${ }^{1}$ In 2011, an additional tax bracket was added for higher incomes and a further one was added again in 2013.
} 
Table 1: The schedule of income tax in Luxembourg in 2009

\begin{tabular}{|c|c|c|c|}
\hline $\begin{array}{l}\text { Bracket } \\
\text { number }\end{array}$ & $\begin{array}{ll}\text { Lower } & \text { limit } \\
\text { (EUR/annum) } & \end{array}$ & $\begin{array}{ll}\text { Upper } & \text { limit } \\
\text { (EUR/annum) } & \end{array}$ & $\begin{array}{l}\text { Rate in } \\
\text { Percent }\end{array}$ \\
\hline 1 & 0 & 11265 & 0 \\
\hline 2 & 11265 & 13173 & 8 \\
\hline 3 & 13173 & 15081 & 10 \\
\hline 4 & 15081 & 16989 & 12 \\
\hline 5 & 16989 & 18897 & 14 \\
\hline 6 & 18897 & 20805 & 16 \\
\hline 7 & 20805 & 22713 & 18 \\
\hline 8 & 22713 & 24621 & 20 \\
\hline 9 & 24621 & 26529 & 22 \\
\hline 10 & 26529 & 28437 & 24 \\
\hline 11 & 28437 & 30345 & 26 \\
\hline 12 & 30345 & 32253 & 28 \\
\hline 13 & 32253 & 34161 & 30 \\
\hline 14 & 34161 & 36069 & 32 \\
\hline 15 & 36069 & 37977 & 34 \\
\hline 16 & 37977 & 39885 & 36 \\
\hline 17 & 39885 & & 38 \\
\hline
\end{tabular}

Source: $O E C D$

\subsection{Marginal and average tax rates}

Incentives to work are often measured using the average or the marginal tax rate. The average tax rate (ATR) is defined as the total tax paid divided by total income while the marginal tax rate (MTR) is defined as the income tax rate applied for a specific tax bracket. The higher the marginal tax rate a worker faces, the more will be taxed away from each additional Euro earned. A situation in which the gap between average and marginal tax rates is high indicates that the amount of tax paid is relatively low but the additional amount of earnings that will be taxed away is relatively high. One important characteristic of the Luxembourg taxation system is that MTRs exceed ATRs by a large margin (see Figure 1). High MTRs reduce the incentive to work extra hours for those already in the labour force and may also reduce the incentive to join the 
labour force in the first place, especially for the secondary earner in a couple in a system of joint taxation.

Figure 1. Marginal Tax Rate (MTR) and Average Tax Rate (ATR) of couple household in Luxembourg in 2009.

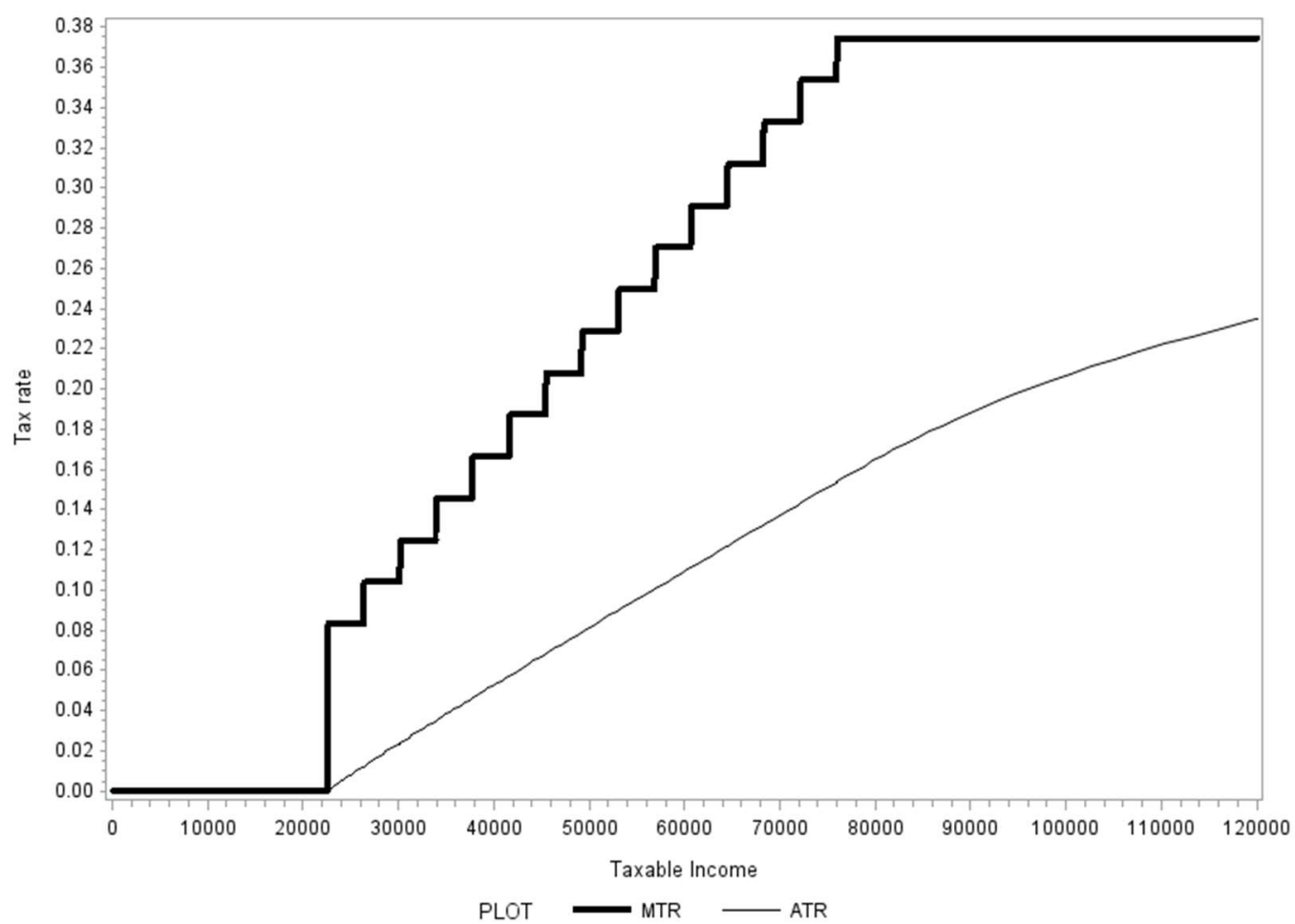

Note: Marginal Tax Rate (MTR) and Average Tax Rate (ATR) of couple household of Luxembourg tax system $2009 / 2010$

Source: Own calculations from LuxTaxBen.

\subsection{Tax incidence}

In this section we present the incidence of taxation among couple households in 2009. Figures 2.1 and 2.2 display the average tax rate (ATR) and marginal tax rate (MTR) for couple households aged less than 65. The situation for the joint system in place in 2009 as well as for a hypothetical individual system in the same year are presented.

Figure 2.1a shows that, in the system of joint taxation, the proportion of couple households in each ATR category is declining as the ATR increases. In the individual taxation system, depicted in Figure 2.1b, the pattern is more irregular with fewer households in the lowest ATR category but more in higher ATR categories. Almost 24\% of households have a zero ATR in 
the joint taxation system compared to just $8 \%$ in the individual tax system, indicating the higher tax burden imposed on low earning households in an individual taxation system.

Figure 2.2 displays MTRs, which affect the household's economic incentive to work more. Almost $9 \%$ of households have a MTR close to zero under the joint taxation system while fewer than $2 \%$ of households have a zero MTR under the individual tax system. Furthermore, almost $21 \%$ households have a MTR close to the top (40\%) under the joint tax system compared to $7 \%$ under the individual tax system. ${ }^{2}$

So, while moving to individual taxation increases average tax rates for couple households, it decreases their marginal tax rate, a shift that can typically be expected to increase labour supply particularly for secondary earners.

Figure 2.1. The proportion of households (aged 18-65) at each Average Tax Rate

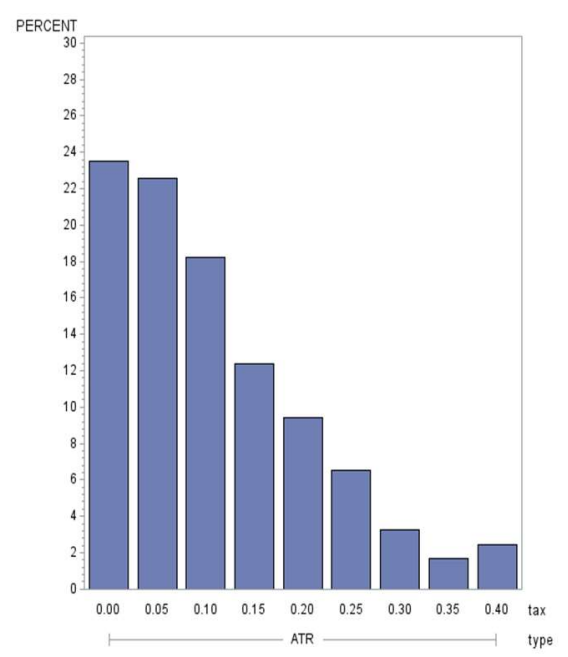

a. Joint taxation

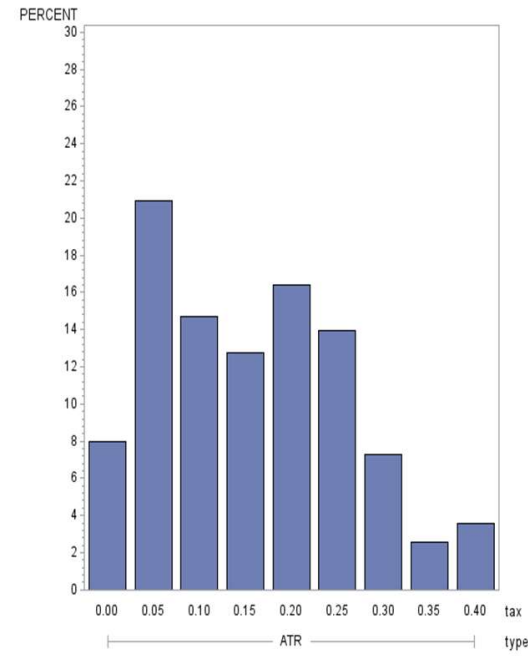

b. Individual taxation

\footnotetext{
${ }^{2}$ The top marginal tax rate is not internationally high. For example top marginal tax rates in 2009 are $35 \%$ for the USA, $40 \%$ for the UK, $50 \%$ for Austria, $40 \%$ for France and 45\% for Australia (OECD)
} 
Figure 2.2 The proportion of households (aged 18-65) at each Marginal Tax Rate

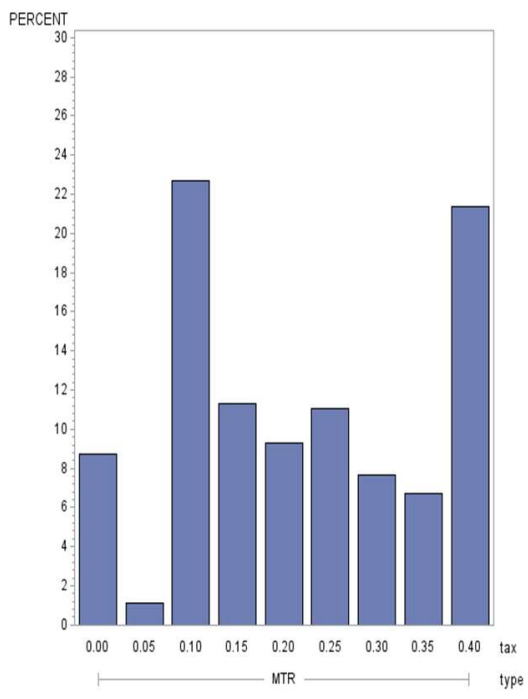

Joint taxation

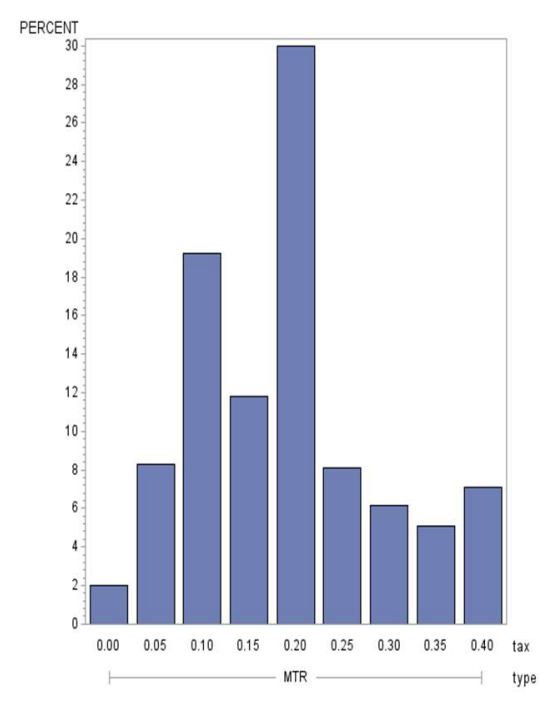

b. Individual taxation

Note: Average Tax Rate (ATR) and Marginal Tax Rate (MTR) of Luxembourg tax payers of 2009/2010 fiscal year.

Source: Own calculations using LuxTaxBen.

\section{Data and preliminary analysis}

\subsection{Summary statistics}

In our analysis, we use the Socio-Economic Panel "Living in Luxembourg" / Panel socioéconomique "Liewen zu Letzebuerg" (PSELL III) data ${ }^{3}$. This data is the Luxembourgish version of the European Union-Statistics on Income and Living Conditions (EU-SILC) and includes variables on various sources of income, benefits (means tested as well as non means tested), wages, basic individual and household characteristics such as age, gender, education, nationality, marital status, employment status, children and region. Cross-border workers represent a sizable proportion of the labour force in Luxembourg. EU-SILC collects data only relating to resident households so this sample of cross-border workers is necessarily excluded from our analysis. Households in which both spouses are unavailable for the labour market, on

\footnotetext{
${ }^{3}$ One of the limitation of this paper is that we did not use very recent data. We use data from EU-SILC 2010, which is rather old. The reason is that the access of recent data is very demanding and the characteristics of the recent data are not expected very different compare to data 2010.
} 
disability benefit, in education, or retired are excluded as their labour supply is rather inelastic. ${ }^{4}$ We select households in which the head of the household is aged between 18 to 65 inclusive. ${ }^{5}$ Table 2 shows weighted summary statistics for this sample of 2,276 resident couple households in which both spouses are available for the labour market (i.e. not in education, disabled or retired). The husband is, on average, older than the wife at 46 compared to 43 . He also has slightly higher education. In line with national statistics for Luxembourg, just half of the sample are of Luxembourgish nationality.

The husbands in our sample have, on average, many more years of work experience than their wives (26 compared to 16). They also have higher hourly wages and are much more likely to be employed. $73 \%$ of married men work full-time, $6 \%$ work part-time while $21 \%$ do not work. In contrast, just $31 \%$ of married women work full-time, a further $28 \%$ work part-time and $41 \%$ do not work. These statistics give a participation rate of $79 \%$ for married men and $59 \%$ for married women. The 20 percentage point gap between the participation rate of married men and married women suggests that there is considerable margin for financial or other incentives to increase the labour supply of the latter.

\footnotetext{
${ }^{4} \mathrm{We}$ also dropped households from the sample for whom information in the data is inconsistent. For example, individuals with missing income as well as individuals with 0 hours of work but positive income have been discarded. Households with more than one married couple as well as households with one or three married individuals are also excluded.

${ }^{5}$ The statutory retirement age in Luxembourg is 65
} 
Table 2: Summary statistics for married households in Luxembourg

\begin{tabular}{|c|c|c|c|c|}
\hline Variable & Mean & Minimum & Maximum & Std Dev \\
\hline Age (husband) & 46.03 & 21 & 65 & 10.55 \\
\hline Age (wife) & 43.1 & 20 & 65 & 10.45 \\
\hline Pre-primary education (husband) & 0.28 & 0 & 1 & 0.45 \\
\hline Pre-primary education(wife) & 0.31 & 0 & 1 & 0.46 \\
\hline Primary or lower secondary & & & & \\
\hline education(husband) & 0.09 & 0 & 1 & 0.29 \\
\hline Primary or lower secondary education(wife) & 0.14 & 0 & 1 & 0.34 \\
\hline Higher or post-secondary education(husband) & 0.35 & 0 & 1 & 0.48 \\
\hline Higher or post-secondary education(wife) & 0.32 & 0 & 1 & 0.47 \\
\hline Tertiary education(husband) & 0.24 & 0 & 1 & 0.42 \\
\hline Tertiary education(wife) & 0.22 & 0 & 1 & 0.42 \\
\hline Hourly wage(husband) & 26.34 & 0.88 & 295.66 & 18.85 \\
\hline Hourly wage(wife) & 20.32 & 0.56 & 433.53 & 15.16 \\
\hline Annual hours of work(husband) & 1738.38 & 0 & 5428.26 & 1053.15 \\
\hline Annual hours of work(wife) & 897.19 & 0 & 6692.64 & 936.49 \\
\hline Luxembourgish(husband) & 0.52 & 0 & 1 & 0.5 \\
\hline Luxembourgish(wife) & 0.49 & 0 & 1 & 0.5 \\
\hline Years of experience (husband) & 26.18 & 0 & 50 & 11 \\
\hline Years of experience (wife) & 15.57 & 0 & 52.42 & 10.2 \\
\hline Not working (husband) & 0.21 & 0 & 1 & 0.41 \\
\hline $\begin{array}{l}\text { Not working } \\
\text { (wife) }\end{array}$ & 0.41 & 0 & 1 & 0.49 \\
\hline Part-time work (husband) & 0.06 & 0 & 1 & 0.23 \\
\hline Part-time work (wife) & 0.28 & 0 & 1 & 0.45 \\
\hline Full-time work (husband) & 0.73 & 0 & 1 & 0.44 \\
\hline Full-time work (wife) & 0.31 & 0 & 1 & 0.46 \\
\hline $\begin{array}{l}\text { Number of } \\
\text { children }(<=18)\end{array}$ & 1.16 & 0 & 7 & 1.17 \\
\hline Observations & 2276 & & & \\
\hline
\end{tabular}

Note: We use the cross-sectional EU-SILC survey data of year 2010 (income year 2009) where cross-border workers, cohabiting couples, household more than one couple are excluded. Source: Own calculations using LuxTaxBen. 


\subsection{Budget constraints}

Figure 3 shows that the married households in which the spouses have unequal incomes lose money in an individual taxation regime compared with a joint taxation regime. The black line shows the household gross income when the primary earner works 40 hours per week at EUR26 per hour (the median male wage) and the secondary earner works between 0 and 50 hours per week at EUR21 per hour (the median female wage). The grey lines show the disposable income of the household in the two taxation regimes. In the joint taxation system (dashed grey line), the initial disposable income is large (as the primary earner uses the secondary earner's tax credits and tax bands) but decreases rapidly compared to gross income as the secondary earner joins the labour force and increases her hours of work. By contrast, in the individual system (solid grey line), disposable income starts off lower but decreases more slowly compared to gross income as the secondary earner increases her hours of work. The incentive for the secondary earner to work is, therefore, larger than in the joint taxation system. In a situation where both spouses in this hypothetical household are working full-time, there is little difference between the disposable incomes implied by the joint or individual taxation system. The main difference lies in the situation where the primary earner works full-time and the secondary earner works between 0 and 20 hours per week.

Figure 3: Household budget constraint for Luxembourg

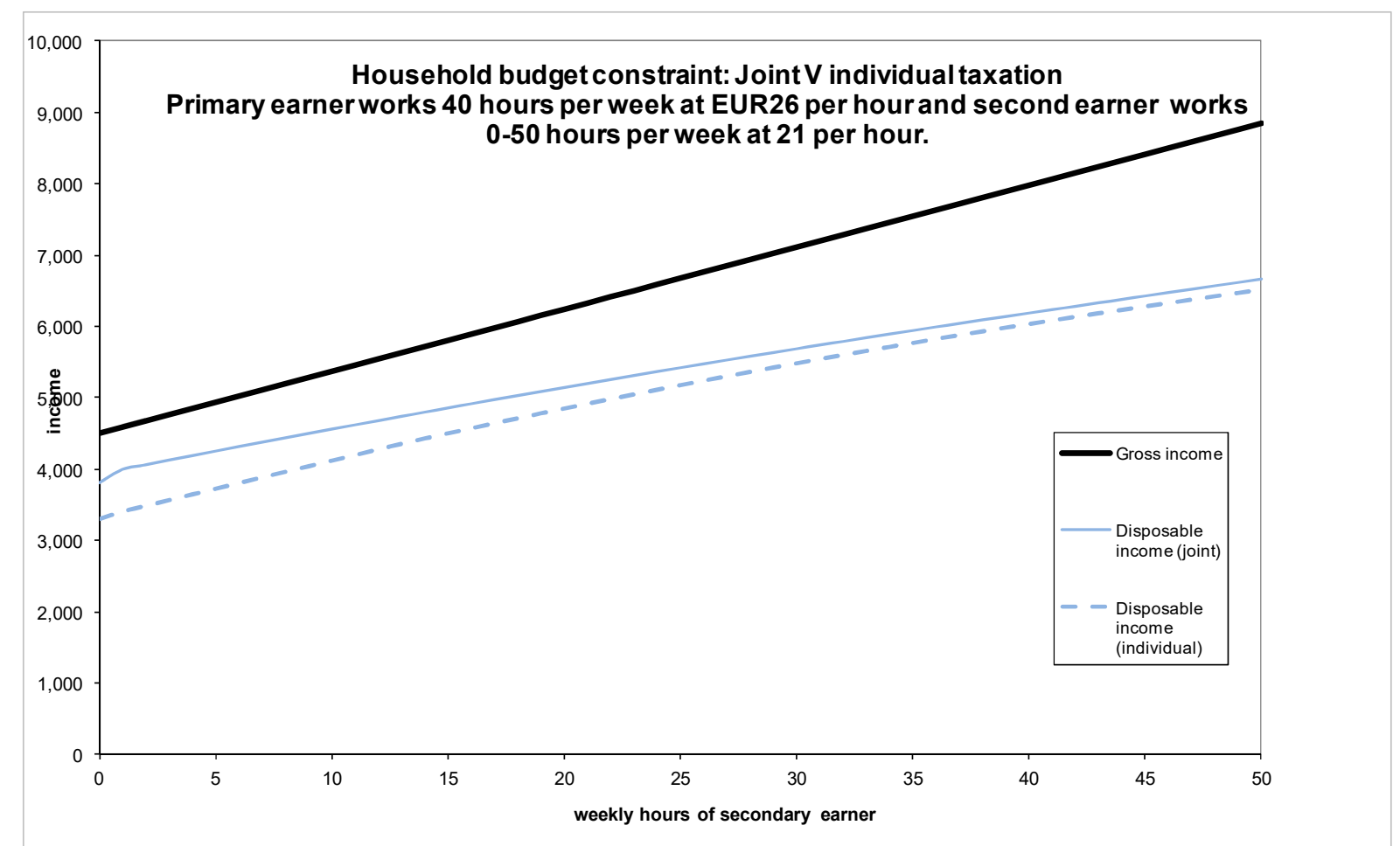

Note: Own calculations using the 2009 EUROMOD system for Luxembourg. 
Next, we look at the individual budget constraint for the secondary earner in this household in Figure 4. To construct this budget constraint, we assume that the primary earner's labour supply is fixed at 40 hours per week. The gross income of the secondary earner is her labour income. The tax attributed to the secondary earner is the difference between the household tax bill if she works 0 hours and the household tax bill if she works between 1 and 50 hours while the disposable income attributed to the secondary earner is the difference between the household disposable income if she works 0 hours and the household disposable income if she works between 1 and 50 hours $^{6}$. As soon as the secondary earner joins the labour market, we see a large increase in her disposable income. This is because of the abattement extra-professionnel, an annual tax credit of EUR 4,500 afforded to married couples in which both spouses work. Disposable income increases by more in the individual regime than in the joint regime as the secondary earner has access to her own tax credits and low band rates. Disposable income increases as the secondary earner provides more hours of work and increases faster in the individual taxation system than in the joint taxation system although the two lines are almost parallel once the secondary earner reaches 40 hours per week, suggesting that she has exhausted her tax credits and access to lower tax bands. This is confirmed in Figure 3 which shows little difference between the household budget constraints under either regime once both spouses work full-time. The difference that remains between the individual budget constraints for the secondary earner once both spouses are working full-time can be attributed to the primary earner. Individually, the primary earner pays more tax with individual taxation than joint taxation, regardless of the working hours of the spouse. ${ }^{7}$

\footnotetext{
${ }^{6}$ This is a rather extreme interpretation of how taxation is allocated between spouses in a joint taxation system but it illustrates nicely the disincentive effect of joint taxation on the labour supply of the secondary earner. An alternative way of thinking about the allocation is to assume that taxation is attributed to each spouse in proportion to their labour income. Budget constraints drawn using this assumption show the same story, albeit in a less dramatic fashion.

${ }^{7}$ Once this increase in the tax bill for the primary earner is added to the decrease in the tax bill for the secondary earner, we arrive at the household budget constraint depicted in Figure 3.
} 
Figure 4: Individual budget constraint for secondary earner in Luxembourg

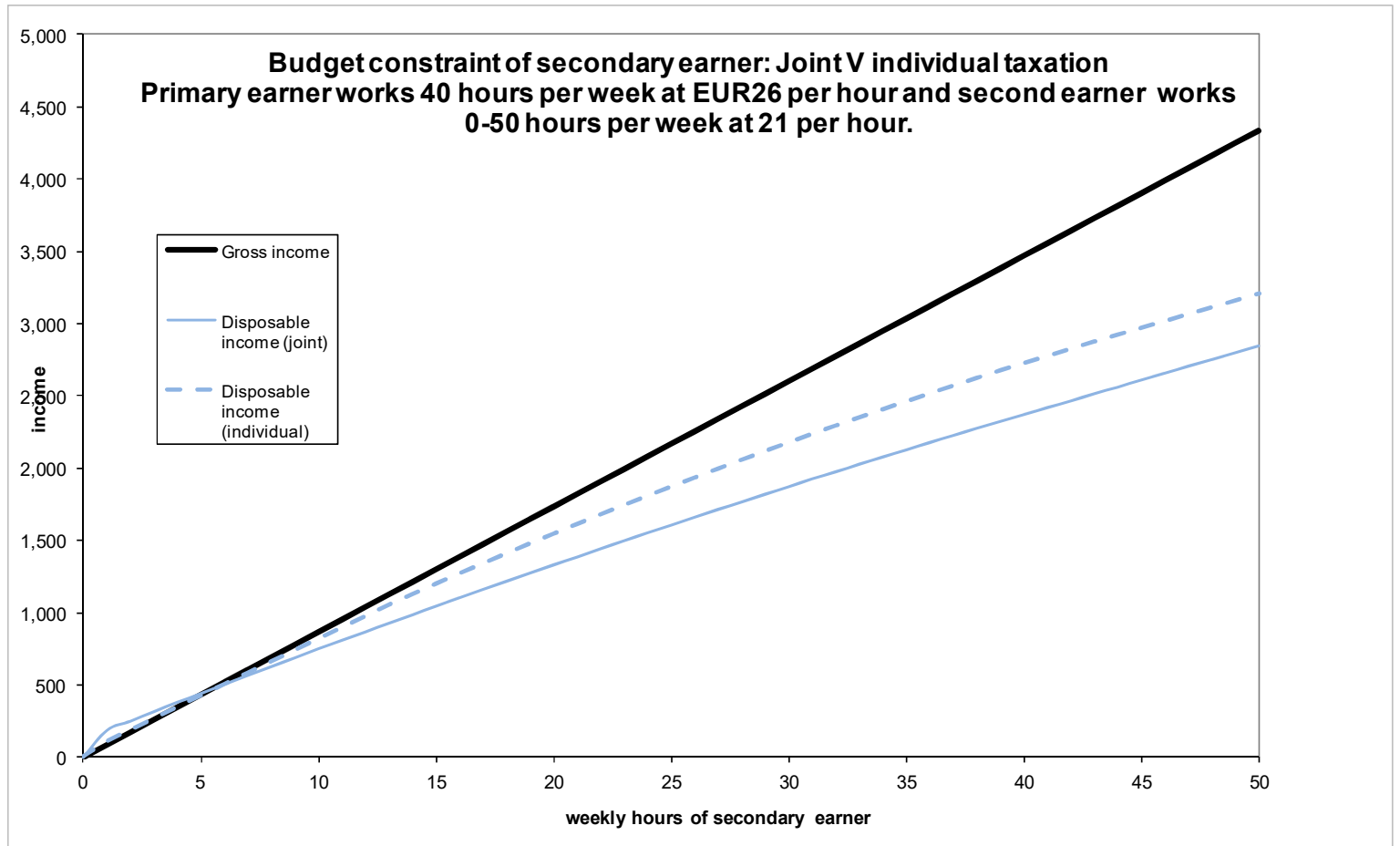

Note: Own calculations using the 2009 EUROMOD system for Luxembourg.

\section{Empirical approach}

To simulate the distributive effect of switching from joint to individual tax we make use of Luxembourg's tax benefit micro simulation model LuxTaxBen ${ }^{8}$ (Islam and Flood 2015). We check the robustness of our results by comparing them with results from the Luxembourg element of EUROMOD, the EU-27 harmonised tax-benefit calculator.

Using PSELL-3 data from 2010 (income reference period 2009) and Luxembourgish tax benefit rules for 2009, LuxTaxBen simulates household disposable income before (joint tax system) and after (individual tax system) the hypothetical reform. Next, the model is used to simulate the behavioural reaction to the reform by employing a flexible structural model of labour supply. Finally, the welfare implications of the switch to individual taxation are examined.

\footnotetext{
${ }^{8}$ LuxTaxBen is a static microsimulation model which can also simulate behavioural effects of tax-benefit reforms. It contains very precise information on income tax rules, as well as eligibility rules for a number of welfare programs (such as social assistance, housing allowance, etc.) allowing us to generate disposable income for various combinations of hours of work and welfare. It has been built in an integrated way so that all the modules including labor supply can be used together.
} 


\subsection{The structural labour supply model}

To evaluate individual behavioural reactions induced by switching from joint to individual taxation we use a direct translog utility model $^{9}$ as proposed by van Soest $(1995)^{10}$.

$$
\begin{gathered}
U(C, L)=\alpha_{1} \log C+\alpha_{11} \log C^{2}+\alpha_{2} \log L_{m}+\alpha_{22} \log L_{m}^{2}+\alpha_{3} \log L_{f}+\alpha_{33} \log L_{f}^{2}+\alpha_{12} \log C \\
\quad * \log L_{m}+\alpha_{13} \log C * \log L_{f}+\alpha_{23} \log L_{m} * \log L_{f}+\alpha_{4} P_{S A}-\beta_{f c m} D_{m} \\
-\beta_{f c f} D_{f}
\end{gathered}
$$

Where $\mathrm{C}$ is household disposable income, leisure is the difference between the time endowment, $T$ (4000 hours per year or almost 80 hours per week), and hours of work, $h_{j}$.

$$
L_{j}=T-h_{j} \text { where } j=\text { male } / \text { female }
$$

Three different intervals or annual working hours $(0,1-1500 \text {, and }>1500)^{11}$ for each member of the couple as well as two states of welfare participation for each household $\left(P_{S A}=0\right.$ or 1$)$ are considered. The choice set for a couple household therefore contains $18(3 * 3 * 2)$ choice sets. A common practice in the formulation of discrete choice labour supply model is to ignore the simultaneity between the decision to work and the decision to receive the Revenu Minimum Garanti (RMG) transfers ${ }^{12}$. However, not all individuals who choose not to work choose to take up their RMG entitlements. The take-up of Luxembourg's main form of Social Assistance, a means tested minimum income, the Revenu Minimum Garanti (RMG), has been estimated to be just one-third (Amétépé 2012). By ignoring the simultaneous decisions of labour market and welfare participation, the costing of tax-benefit reforms in a microsimulation framework may be misleading by overestimating the financial gain to the government of increases in labour supply. Therefore, we introduce $P_{S A}$, a dummy variable for welfare participation, to the model. $P_{S A}$ is one if the household receives the RMG and zero otherwise. Fixed costs of work are also accounted for by $D_{j}$ where $D_{j}$ is equal to one if working hours are above zero. To

\footnotetext{
${ }^{9}$ Nowadays this approach has become a standard method and applied in huge literature ( see for example Blundell et al. 2000, Flood et al. 2004, Berger et al. 2011).

${ }^{10}$ For the advantage of using discrete choice over continous model see for example Flood and Islam (2005), Creedy and Duncan (2002).

${ }^{11}$ In this paper we use annual hours of work rather than weekly as is more common in the literature. Our model deals with tax, social security, tax deductions and allowances. These variables are, in general, annually determined. Thus, an annual measure of hours makes more sense than weekly hours (see Flood et al, 2004 for previous work using annual hours of work).

${ }^{12}$ The main form of social assistance, the RMG, is calculated at the household level in both the joint and individual systems. In the individual system, it is split equally between the partners. Around $7 \%$ of households receive social assistance in both the joint and individual systems. Therefore, we follow Flood et al. (2004) who estimate labor supply and welfare participation decision simultaneously.
} 
account for observed and unobserved preferences for leisure and welfare participation, a set of parameters for individual and household characteristics as well as a set of random terms are also included in the model. The preferences parameters and random terms are introduced as follows:

$$
\begin{array}{ll}
\text { for maleleisure } & \alpha_{2}=\sum_{k=1}^{\mathrm{K}} \alpha_{2, k} x_{k}+v_{m} \\
\text { for female leisure } & \alpha_{3}=\sum_{k=1}^{\mathrm{K}} \alpha_{3, k} x_{k}+v_{f} \\
\text { for welfare participation } & \alpha_{4}=\sum_{l=1}^{\mathrm{L}} \alpha_{4, l} z_{l}+v_{P_{S A}}
\end{array}
$$

The $x$-vector includes $k$ observed characteristics such as age, level of education, number of children in the household and a regional dummy. The $z$-vector includes $l$ observed characteristics such as age, level of education, number of children in the household and a regional dummy. The $v$ represents unobserved random terms that account for preferences for leisure for male $\left(v_{m}\right)$, female $\left(v_{f}\right)$ and welfare participation $\left(v_{P_{S A}}\right)$. In order to define the distribution of $v$, we follow the Heckman and Singer (1984) approach and apply a finite mixture model where the distribution of $v$ corresponds to three different sets $\left\{\left(\theta_{\mathrm{m} 1}, \theta_{\mathrm{m} 2}, \theta_{\mathrm{m} 3}\right)\right.$, $\left(\theta_{\mathrm{f} 1}, \theta_{\mathrm{f} 2}, \theta_{\mathrm{f} 3}\right)$, and $\left.\left(\theta_{\mathrm{SA} 1}, \theta_{\mathrm{SA} 2}, \theta_{\mathrm{SA} 3}\right)\right\}$ of mass points $(\mu)$ each with probability $\pi(\pi>0$ and $\Sigma$ $\pi=1)$. The contribution to the likelihood function, $l f$, is then:

$$
\text { If }=\sum_{\mu=1}^{3} \pi_{\mu}\left(\sum_{r=1}^{2} \sum_{q=1}^{3} \sum_{q^{\prime}=1}^{3}(p \mid \Theta)_{q, q^{\prime}, r}\right) \tau_{q, q^{\prime}, r}
$$

where

$$
(p \mid \Theta)_{q, q^{\prime}, r}=\exp \left(U_{q, q^{\prime}, r} \mid \Theta\right) / \sum_{s=1}^{2} \sum_{t=1}^{3} \sum_{w=1}^{3} \exp \left(U_{t, w, s} \mid \Theta\right)
$$

$\Theta=\left\{\theta_{m}, \theta_{f}, \theta_{S A}\right\}$ and $\tau_{\mathrm{q}, \mathrm{q}^{\prime}, \mathrm{r}}$ is an indicator function for the observed state of each household.

Index $q(=1, \ldots, 3)$ represents the male's choice of labour supply, $q^{\prime}(=1, \ldots, 3)$ represents the female's choice of labour supply, $r(=1, \ldots, 2)$ represents the household's welfare participation state, and $U_{q, q^{\prime}, r}$ represents the household utility in state $\left(q, q^{\prime}, r\right)$ which is the highest probability amongst all possible leisure-welfare combinations, conditional on unobserved preferences. 


\subsection{Estimation results and Model prediction}

Equation 1 is estimated using a direct translog utility model that allows both spouses to choose among 18 various combinations of market hours, household disposable income and welfare participation. Estimated parameters are presented in Appendix Table A1. The utility function was found to be increasing with income. ${ }^{13}$ That is, the condition of increasing marginal utility of income is satisfied for the vast majority of households (the condition was rejected for only about $1 \%$ households).

The estimated parameters of the systematic part of the utility function are shown in Appendix Table A1. Males with young children (aged below 5) have a stronger preference for work while females with young children have a stronger preference for leisure. The total number of children has a positive and significant effect on female preferences for leisure but the opposite effect is observed for men. A stronger preference for leisure is further observed in households where the female has a secondary education. However secondary education among men has a negative effect on preferences for leisure. Both men and women living in Luxembourg city have a looser connection to the labour market.

\subsubsection{Random preferences}

Preferences for work may vary randomly through unobservable characteristics. In this section we discuss the estimated distribution of random preferences by a finite mixture model. Finite mixture model also known as latent class models involve techniques to analyse a population where individuals or households can be classified into different subgroups based on their pattern of unobserved characteristics such as preference, motivation, test or ability. This method allows for a relatively unrestricted specification of individual effects (for details see for example Heckman and Singer 1984). The underlying unobserved heterogeneity, which splits the population into three subgroups (three mass points), is assumed to be based on the person's latent preference or ability to work. Three different subgroups of unobserved workpreferences of males are represented by three different mass points as $\theta_{\mathrm{m} 1}, \theta_{\mathrm{m} 2}, \theta_{\mathrm{m} 3}$ and the same is true for female work preferences $\left(\theta_{\mathrm{f} 1}, \theta_{\mathrm{f} 2}, \theta_{\mathrm{f} 3}\right)$. Similarly, there are three mass points

\footnotetext{
${ }^{13}$ For more information about this issue see for example Lebeaga et al., (2008), Van Soest and Das, (2001), Vlasblom (2001), and Liegeois and Islam (2013).
} 
$\theta_{\mathrm{SA} 1}, \theta_{\mathrm{SA} 2}, \theta_{\mathrm{SA} 3}$ for household unobserved preferences for social welfare (RMG). The density of each subgroup is represented by $\pi_{1}, \pi_{2}$ and $\pi_{3}$.

Results are presented in the second part of Table A1. The estimated mass points for men's preferences for leisure are $\theta_{m 1}=-0.94, \theta_{m 2}=-0.22$, and $\theta_{m 3}=1.16$, for female partners are $\theta_{f 1}=2.23 \theta_{f 2}=3.20$ and $\theta_{f 3}=-5.43$ and for welfare participation are $\theta_{S A 1}=2.42$ , $\theta_{S A 2}=-2.50$, and $\theta_{S A 3}=0.08$. Each mass point represents the random factors with corresponding probabilities $\pi_{1}=0.70, \pi_{2}=0.21$ and $\pi_{3}=0.09$. These results indicate that $70 \%$ of male partners $\left(\pi_{1}=0.70\right)$ belong to the $1^{\text {st }}$ group $\left(\theta_{m 1}=-0.94\right), 21 \%$ belong to the $2^{\text {nd }}$ group $\left(\theta_{m 2}=-0.22\right)$ and $9 \%$ belong to the $3^{\text {rd }}$ group $\left(\theta_{m 3}=1.16\right)$. The majority of male partners, therefore, has strong preferences for work over leisure. Just $9 \%$ of males in couples have weak preferences for work over leisure. For female partners, the results show that $70 \%$ of female partners belong to the first group $\left(\theta_{f 1}=2.23\right)$ and have relatively moderated preferences for leisure while 9\% have a strong preference for work over leisure. Concerning preferences for welfare participation, results shows that around $70 \%$ of welfare recipienthouseholds have strong preferences for leisure over work $\left(\theta_{S A 1}=2.42\right)$.

\subsubsection{Model Predictions}

We test the fit of the model by comparing predicted to actual hours of work. We find that predicted hours are very similar to actual hours for both males and females (see Table 3 ). The predicted welfare participation for couple households is also very similar to the actual welfare participation (see Table 4). 
Table 3 The percentages of actual and predicted working hours for males and females in couples with 18 combinations using PSELL 2010 (income year 2009).

\begin{tabular}{|ll|lll|}
\hline & & 0 Hour & $1-1500$ Hours & $>1500$ Hours \\
\hline Male & Predicted & 21.31 & 5.05 & 73.64 \\
& Actual & 21.40 & 5.67 & 72.93 \\
\hline \multirow{2}{*}{ Female } & Predicted & 40.51 & 28.73 & 30.76 \\
& Actual & 41.17 & 27.55 & 31.28 \\
\hline
\end{tabular}

Note: We use the cross-sectional EU-SILC survey data of year 2010 (income year 2009) of 2276 couple household of Luxembourg linked to LuxTaxBen. Labour supply and welfare participation decisions of partners in couples have been estimated jointly.

Table 4. The percentages of actual and predicted welfare participation of couple household with 18 combinations using PSEL 2010 (income year 2009).

\begin{tabular}{|l|cc|}
\hline \multirow{2}{*}{ Not welfare recipient } & $\begin{array}{c}\text { Actual } \\
\text { proportion }\end{array}$ & $\begin{array}{c}\text { Predicted } \\
\text { proportion }\end{array}$ \\
\cline { 2 - 3 } Welfare recipient & 93.06 & 93.15 \\
& 6.94 & 6.85 \\
\hline
\end{tabular}

Note: We use the cross-sectional EU-SILC survey data of year 2010 (income year 2009) linked to LuxTaxBen and jointly estimate labour supply and welfare participation where welfare concern only the integration allowance ( for details see footnote 11).

\subsection{Labour supply elasticities}

There is an abundant literature on labour supply elasticities. Different studies report elasticities of different magnitudes (and sometimes sign), depending on methodological choices, including the type of data used (tax register data or interview-based surveys), sample selection (e.g. households with or without children), the period of observation and the estimation method (see for example Heim, 2007, Kornstad and Thoresen, 2007, Fuchs et al., 1998, Bargain and Peichl, 2014). However, there is consensus that females usually have a higher wage elasticity than males. 
Table 5. Effect of $10 \%$ wage increase on labour supply of men and women in couples ${ }^{14}$

\begin{tabular}{|c|c|c|c|c|c|c|}
\hline $\begin{array}{c}\text { Labor } \\
\text { supply } \\
\text { effect }\end{array}$ & $\begin{array}{c}10 \text { th } \\
\text { percentile }\end{array}$ & $\begin{array}{c}25 \text { th } \\
\text { percentile }\end{array}$ & $\begin{array}{c}\text { 50th } \\
\text { percentile }\end{array}$ & $\begin{array}{c}\text { 75th } \\
\text { percentile }\end{array}$ & $\begin{array}{c}\text { 90th } \\
\text { percentile }\end{array}$ & Overall \\
\hline Female & 2.63 & 1.15 & 0.19 & 0.54 & 0 & 0.44 \\
\hline & \multicolumn{7}{c}{0.61} & 0 & 0 & 0.29 \\
\hline Male & 3.74 & 1.21 & 0.61 & & & \\
\hline
\end{tabular}

Source: Own calculations using LuxTaxBen.

We simulate the elasticities by increasing gross wages by $10 \%$ (the elasticities in the Table 5 are expressed as the percentage change in labour supply for a $10 \%$ increase in gross wages). The results show that a $10 \%$ increase in the female wage rate raises the overall labour supply of married women by about $0.44 \%$ while a $10 \%$ increase in the male wage rate increases the labour supply of married men by about $0.29 \%$. The result implies very low labour elasticities.

\section{Simulation Results}

\subsection{Fiscal impact}

We believe the cleanest way to analyze a transition from joint to individual taxation, is to simulate a scenario that is neutral for the government budget. So we simulate the transition, and modify taxes at the same time to keep the government budget neutral. We expect two distinct effects of individualization of the taxation system on fiscal budgets. The first round or morning after effect and the behavioural or second round effect. The first round effects of a tax policy change explain in simple terms "the tax changes" without labour supply or behavioural response. The second round effects of a tax policy change refer to labour supply responses with wage rates held constant. Table 6 demonstrates the aggregated outcomes for the central governmental budget. The magnitude of these effects is displayed in columns 3 and 5, respectively. The result (column 3) shows the budget effect of 2,276 couple's households ${ }^{15}$ (for whom selection criteria was explained in section 3). Indeed, no changes in an individual taxation system when behavioural response is not taken into account. This is entirely due to revenue neutral budget of individualisation tax system. A further fiscal effect comes through indirect tax receipts. The effect of increasing or decreasing household disposable income will have knock-on effects on consumption and, therefore, on VAT receipts. The standard VAT rate

\footnotetext{
${ }^{14}$ We also calculate(not reported) the cross elasticity and the effect is essentially zero.

${ }^{15} \mathrm{We}$ did not focus on the tax treatment of single households because the single household are not relevant of the policy reform.
} 
in Luxembourg was $15 \%$ in 2009 . Therefore, we calculate the change in VAT receipts as the change in disposable income multiplied by the VAT rate. ${ }^{16}$ Once labour supply adjustment (see column 5) is taken into account, disposable income increases by around 32Milion EURO and tax revenue increases by around 0.25 Milion EURO. Once the reduction in VAT receipts is taken into account, this results in a fiscal surplus of $€ 10$ million.

Table 6. The effect of an individual tax reform on central governmental budget using cohabiting sample age 18-65 (in EURO)

\begin{tabular}{|c|c|c|c|c|c|}
\hline \multirow{2}{*}{$\begin{array}{c}\text { Macro level } \\
\text { (EURO) }\end{array}$} & \multicolumn{3}{|c|}{ Without behavioural adjustment } & \multicolumn{2}{|c|}{ With behavioural adjustment } \\
\hline & Joint Tax & Individual Tax & Change & Individual Tax & Change \\
\hline & 1 & 2 & 3 & 4 & 5 \\
\hline Disposable income & $5,917,034,919$ & $5,917,034,921$ & 3 & $5,949,273,203$ & $32,238,284$ \\
\hline Labour income & $5,993,404,021$ & $5,993,404,021$ & 0 & $6,030,981,299$ & $37,577,278$ \\
\hline Pension & $676,590,748$ & $676,590,748$ & 0 & $676,590,748$ & 0 \\
\hline Total tax & $817,975,424$ & $817,975,422$ & -2 & $818,223,386$ & 247,962 \\
\hline \multicolumn{6}{|l|}{ Transfers } \\
\hline Unemployment & $144,158,621$ & $144,158,621$ & 0 & $144,158,621$ & 0 \\
\hline Social assistance & $56,567,731$ & $56,567,731$ & 0 & $56,228,256$ & $-339,476$ \\
\hline VAT & & 0.45 & & & $4,836,742$ \\
\hline Social security & $805,070,123$ & $805,070,123$ & 0 & $809,416,441$ & $4,346,319$ \\
\hline Budget effect & & & 1.55 & & $9,770,499$ \\
\hline \multicolumn{4}{|c|}{ Change in tax revenue due to behavioural response } & 00.55EURO & \\
\hline
\end{tabular}

VAT is calculated $15 \%$ (the standard rate) of disposable income. For simulation, we use labour supply parameter obtained from the sample of married couples. Source: Own calculations using LuxTaxBen.

\subsection{Labour supply response}

Table 7 shows the labour supply response to switching from joint to individual taxation in Luxembourg. Married men's working hours can be expected to marginally decrease (by $0.13 \%)$. On the other hand, the hours of work of married women can be expected to increase by $2.27 \%$. At the extensive margin, an increase in the labour force participation rate of $0.03 \%$ for men is noted while an increase in the labour force participation rate of married women of

\footnotetext{
${ }^{16}$ There was no change of the standard VAT rate between 1992 to 2015 . It was increased from $15 \%$ to $17 \%$ in 2015.
} 
$2.58 \%$ can be expected. We calculate the standard error of these percentage changes at the mean using the delta method. The last column of Table 7 shows that the percentage change in working hours and participation for males is statistically insignificant while that of females is statistically significant at the $1 \%$ level.

Table 7. Change in working hours and participation (Sample size 2,276)

\begin{tabular}{|c|c|c|c|c|c|}
\hline Working hours & $\begin{array}{c}\text { Joint } \\
\text { Taxation(x) }\end{array}$ & $\begin{array}{c}\text { Individual } \\
\text { Taxation(y) }\end{array}$ & $\operatorname{Abs}(y-x)$ & $\% \operatorname{Abs}((y-x) / x)$ & $\begin{array}{c}\text { Standard } \\
\text { error of } \\
\% \\
\text { change } \\
\text { at the } \\
\text { mean }\end{array}$ \\
\hline \multicolumn{6}{|l|}{ Working hours (Male) } \\
\hline Total & $136,918,512$ & $136,742,508$ & $-176,004$ & -0.13 & \multirow{3}{*}{$0.199^{\mathrm{ns}}$} \\
\hline Mean & 1715.94 & 1713.54 & 2.4 & 0.14 & \\
\hline $\mathrm{SE}$ & 5506.79 & 5508.61 & 1.82 & 0.03 & \\
\hline \multicolumn{6}{|l|}{ Working hours (Female) } \\
\hline Total & $74,103,770$ & $75,785,533$ & $16,817,63$ & 2.27 & \multirow{3}{*}{$0.385^{* * *}$} \\
\hline Mean & 928.71 & 949.79 & 21.08 & 2.27 & \\
\hline SE & 5694.32 & 5687.73 & 6.59 & 0.12 & \\
\hline \multicolumn{6}{|l|}{ Participation (Male) } \\
\hline Total & 63,302 & 63,320 & 18 & 0.03 & \multirow{3}{*}{$0.167^{\mathrm{ns}}$} \\
\hline Mean & 0.79333 & 0.79356 & 0.00036 & 0.05 & \\
\hline SE & 2.39703 & 2.39799 & 0.00096 & 0.04 & \\
\hline \multicolumn{6}{|l|}{ Participation (Female) } \\
\hline Total & 47,243 & 48,462 & 1219 & 2.58 & \multirow{3}{*}{$0.308^{* * *}$} \\
\hline Mean & 0.59208 & 0.61098 & 0.01886 & 3.19 & \\
\hline SE & 2.9105 & 2.89208 & 0.01884 & 0.63 & \\
\hline
\end{tabular}

Note: $* * *$ indicates level of significant at $1 \%$ and ns indicates not significant. Using delta method we have:

$\operatorname{Var}(100 *(\bar{y}-\bar{x}) / \bar{x}) \approx 100{ }^{2} * \operatorname{Var}(\bar{y} / \bar{x}) \approx 1002 *\left(\frac{\bar{y}}{\bar{x}}\right)^{2}\left(\frac{\operatorname{Var}(\bar{x})}{\bar{x}^{2}}+\frac{\operatorname{Var}(\bar{y})}{\bar{y}^{2}}\right)$

$S E(100 *(\bar{y}-\bar{x}) / \bar{x}) \approx 100 *\left(\frac{\bar{y}}{\bar{x}}\right) \sqrt{\left(\frac{\operatorname{Var}(\bar{x})}{\bar{x}^{2}}+\frac{\operatorname{Var}(\bar{y})}{\bar{y}^{2}}\right)}=\frac{100}{n} *\left(\frac{\bar{y}}{\bar{x}}\right) \sqrt{\left(\frac{(S E(x))^{2}}{\bar{x}^{2}}+\frac{(S E(y))^{2}}{\bar{y}^{2}}\right)}$

\subsection{Winners and losers}

In order to identify winners and losers of policy reforms, in this section, we evaluate the distribution of disposable income caused by a switch from joint to individual taxation. We used unitary household labour supply model (equation 1) to determine the behavioural reaction and ranked households by their equivalised (adjusting for the number of adults and children) disposable income. Figure 5 shows the change in equivalised disposable income, by decile group. Equivalised disposable income, after the behavioural adjustment, decreases on average 
around 2 per cent. The households who gain the most are located in the top of the income distribution while the middle and bottom deciles lose the most. Note that the evaluation are based on a unitary model of the household, where equivalence scales are used to accommodate different needs depending on the family size. However, it is not an ideal measure for evaluating whether a reform should be socially preferred or not. An alternative model entirely based on individual income and welfare would probably register an increase of well-being in the lower part of the individual income distribution, due to the increase of labor supply in the female population.

Figure 5. Percentage change of equalised disposable income by decile after behavioural response to switch to individual taxation reform

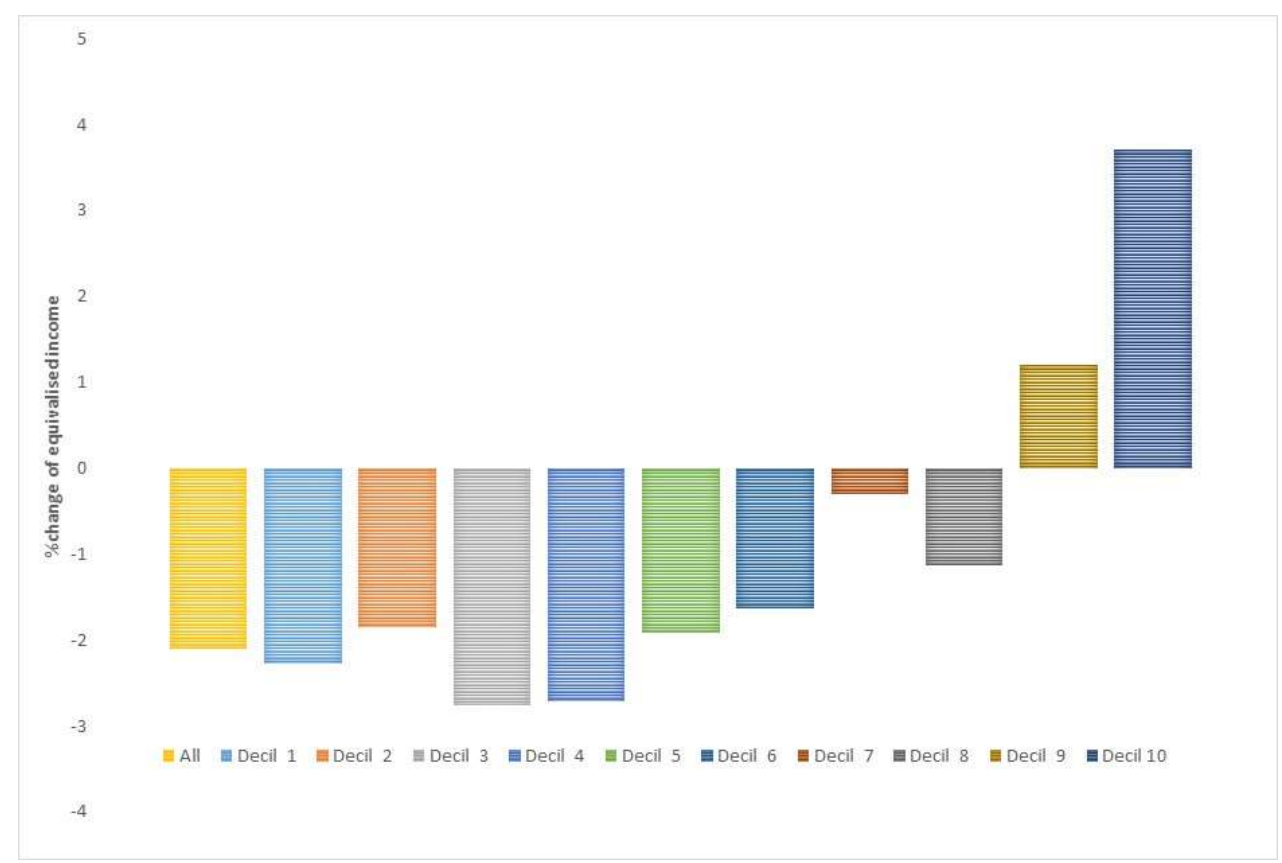

Note: We ranked households by their equivalised (adjusting for the number of adults and number of children) disposable income before the reform. Source: Own calculations using LuxTaxBen.

\subsection{Validation exercise}

In this section we compare our findings from this policy reform in the LuxTaxBen software to findings from the same exercise using the tax-benefit micro simulation software, EUROMOD which is an integrated tax-benefit calculator covering the systems of the EU-27 countries (Sutherland and Figari (2013)). We use the simulation of the 2009 Luxembourg tax-benefit system linked to 2010 EU-SILC data for Luxembourg. This calculator allows the computation of all social contributions, direct taxes and transfers to yield household disposable income. 
With some re-calibration, in which both married couples, civil partners and singles are all recategorized as belonging to tax class 1 , it also simulates the same variables in the hypothetical switch from a system of joint to individual taxation. Using EUROMOD, we simulate the "actual" taxes, social security contributions, benefits and disposable income for each household, given their wage, demographic and other characteristics in 2010. Using the discrete choice labour supply model outlined in Section 4.1, we then model the labour supply of men and women in couples based on their observable characteristics and their disposable income. Simulating the switch to individual taxation, we then compute the "new" disposable income of each household in the data. Using the parameters from the discrete choice labour supply allows us to estimate the change in labour supply of women due to the policy reform as well as the change in fiscal revenue.

Table 8 displays the comparison of the simulation results from moving from joint to individual taxation in the LuxTaxBen software to findings from the same exercise using EUROMOD. The estimation sample is narrowed (1,502 couple households) to ensure comparability between the two software. Columns 1 and 2 in the first row display the percentage change of hours of work for males from LuxTaxBen and EUROMD respectively. In both cases, almost no male changes their hours of work due to the tax reform. Further, columns 1 and 2 in the second row display the percentage change of hours of work for females. Results show that, due to the reform, females increased their hours of work by $2 \%$ using results from LuxTaxBen and by $1.2 \%$ using results from EUROMOD.

Next we compare the effect of the tax reform on household disposable income using results from LuxTaxBen and EUROMOD. Percentage changes in non-adjusted household disposable are presented in the fourth row of Table 8 . The results show a decrease in disposable income of almost 3\% in both cases. In the calculation of household disposable income we differentiate between two components: the change of disposable income due to the reform (first round effect) and the change of disposable income due to the labour supply response (second round effect). The fourth and fifth rows of Table 8 show the first and second round effect of moving from joint to individual tax. Both software show similar findings. The first round effect is -3$4 \%$ while the second round effect is less than $1 \%$. 
Table 8: Comparing simulation results of individual taxation reform in the LuxTaxBen software to findings from the same exercise using EUROMOD

\begin{tabular}{|l|c|c|}
\hline & \multicolumn{2}{|c|}{ Percentage change (in mean value ) } \\
between joint and individual tax system
\end{tabular}

We estimate labour supply and welfare participation jointly using output from LuxTaxBen and EUROMOD.

\section{Conclusion and discussion}

In this paper, we evaluated the effect of moving from joint to individual taxation on female labour supply in couple households in Luxembourg. To simulate the behavioural effect of tax reform we estimated a structural household labour supply model where labour supply as well as participation in welfare of both partners were jointly determined. We used a direct translog utility model that allows both spouses to choose between various combinations of market hours and household disposable income using PSELL 2010 (income year 2009) survey data.

Simulations show that moving from joint to individual taxation may have considerable income, labour supply and welfare effects. The labour supply of married women increases by around $2.27 \%$ after the reform. There is no effect on the labour supply of married men. Equivalised disposable income, after the behavioural adjustment, decreases on average around 2 per cent. The households who gain the most are located in the top of the income distribution while the middle and bottom deciles lose the most. After adjustments to direct, indirect taxes, and revenue neutral budget using proportionate tax-cut, the net result is maximum budget surplus for the central government of around $€ 10$ million. 
One of the caveat of the analysis we did not evaluate the welfare effects from social planner point of view. The welfare measure that we have used in the paper is relevant to measure the change in the level or distribution of disposable income. However, it is not an ideal measure for evaluating whether a reform should be socially preferred or not ${ }^{17}$. Indeed, because of the problem of inter personal comparability; there is no ideal measure to characterize the welfare benefits of the reform. For instance, Islam \& Colombino (2018), Aaberge and Colombino (2013) and many others adopt a procedure that consists of using a common utility function as an argument of the social welfare function following Deaton and Muelbauer (1980) approach ${ }^{18}$. They re-estimated the social preference model that justifies interpersonal comparisons. They consider each individuals as representative singles household to introduce an individual welfare function and adjust for scale economics in consumption by dividing couples' income by the square root of 2. Ericson et al. (2009) and others estimated a social welfare function and used that function as one part of the evaluation of a reform. Yet the problem is intra household inequality aversion, which entirely ignored in the model. Decoster and Haan (2014) provide an empirical application of Fleurbaey and Maniquet's (2011) ethical criteria keeping preference heterogeneity in the normative step of the analysis. The estimated household model (equation 1) that we have used in the paper allows variation in preferences for household income, leisure of each partner, RMG participation decision, and other observable and unobservable characteristics. It does not make sense to consider the model as comparable individual-welfarefunctions. We either can estimate/re-estimate the social preference model or choose any typical measure that justifies interpersonal comparisons. Currently, it is out of scope to investigate and use the approach that would produce a much better understanding of the welfare effects of the individual tax reform but still allowing for the detailed level required in order to keep it at a realistic level.

\footnotetext{
${ }^{17}$ For more details see for example Ericson et al (2009), Decoster and Haan (2014).

${ }^{18}$ This procedure, originally proposed from Mehran (1976) and Yaari (1988), has been applied in other settings (see for example Aaberge and Flood, 2008; Aaberge and Colombino, 2008)
} 


\section{References}

Aaberge, R., \& Colombino, U. (2008). Designing Optimal Taxes with a Microeconometric Model of Household Labour Supply. CHILD Working Paper no. 06/08.

Aaberge, R., Colombino, U., (2013). Using a microeconometric model of household labour supply to design optimal income taxes. Scand. J. Econ. 115 (2), 449-475.

Aaberge, R., \& Flood, L. (2008). Evaluation of an In-Work Tax Credit Reform in Sweden: Effects on Labor Supply and Welfare Participation of Single Mothers. IZA Discussion Paper No. 3736 .

Amétépé F. (2012). The effectiveness of Luxembourg's minimum guaranteed income. International social security review, 65(1), pages 99-116.

Bargain, O., Orsini K, and A. Peichl (2014). Comparing Labor Supply Elasticities in Europe and the United States: New Results. Journal of Human Resources, University of Wisconsin Press, vol. 49(3) .

Berger F., Islam N., Liegeois P. (2011). Behavioral micro simulation model and labor supply in Luxembourg. Brussels Economic Review, 2011, Vol.54.

Bick, A., and Fuchs-Schündeln, N. 2017. Quantifying the Disincentive Effects of Joint Taxation on Married Women's Labor Supply. American Economic Review, 107(5): 100-104.

Blundell, R. and Macurdy, T. (1999). Labor supply: A review of alternative approaches. In Ashenfelter, O. and Card, D., editors, Handbook of Labor Economics, volume 3 of Handbook of Labor Economics, chapter 27, pages 1559-1695. Elsevier.

Blundell R., Duncan A., Mc Crae J., and Meghir C. (2000). The labor market impact of the working families Tax Credit. Fiscal studies 21:75-104.

Colonna, F. and Marcassa, S. (2015). Taxation and female labor supply in Italy. IZA Journal of Labor Policy, Springer; Forschungsinstitut zur Zukunft der Arbeit GmbH (IZA), vol. 4(1). 
Crossley, T. F. and Jeon, S.-H. (2007). Joint Taxation and the Labour Supply of Married Women: Evidence from the Canadian Tax Reform of 1988. Fiscal Studies, 28(3):343-365.

Creedy J. and Duncan A. (2002). Behavioural micro simulation with labour supply responses. Journal of economic survey. Vol 16, No 1.

Deaton, A., Muellbauer, J., 1980. Economics and Consumer Behavior. Cambridge University Press

Dearing, H., Hofer, H., Lietz, C., Winter-Ebmer, R., and Wrohlich, K. (2007). Why Are Mothers Working Longer Hours in Austria than in Germany? A Comparative Microsimulation Analysis. Fiscal Studies, 28(4):463-495.

Decoster, A. and Haan, P. (2014). Welfare Effects of a Shift of Joint to Individual Taxation in the German Personal Income Tax. FinanzArchiv: Public Finance Analysis, Mohr Siebeck, Tübingen, vol. 70(4).

Doorley, K. (2018). Taxation, work and gender equality in Ireland. Journal of the Statistical and Social Inquiry Society of Ireland, forthcoming.

Fleurbaey M. and Maniquet F. (2011). A Theory of Fairness and Social Welfare Cambridge University Press.

Flood L.,R., Hansen J., and Wahlberg R. 2004. Household labor supply and welfare participation in Sweden. Journal of Human Resources 39(4): 1008-1032.

Flood L. and Islam N. (2005). A Monte Carlo evaluation of discrete choice labour supply models. Applied Economics Letters Volume 12, Issue 5.

Fuchs, V.R., A. B. Krueger and J. M. Poterba (1998). Economists. Views about Parameters, Values, and Policies: Survey Results in Labor and Public Economics. Journal of Economic Literature, 36(3), 1387-1425. 
Hausman J., and Ruud P. (1984). Family labor supply with Taxes. American economic Review 74: $242-248$.

Heckman, J. and Singer, B.L. (1984). A method for minimizing the distributional assumptions in econometric models for duration data. Econometrica 52: 271-320.

Heim, B. (2007). The Incredible Shrinking Elasticities: Married Female Labor Supply, 19782002. Journal of Human Resources 42(4): 881.918.

Hey, J.D. and P.J. Lambert (1980). Relative Deprivation and the Gini Coefficient: Comment. Quarterly Journal of Economics 94, 567-573.

Islam Nizamul and Flood Lennart (2015). A Tax Benefit Model for Policy Evaluation in Luxembourg: LuxTaxBen. IZA Discussion Paper No. 9152.

Islam \& Colombino (2018). The case for NIT+FT in Europe. An empirical optimal taxation exercise. Economic Modelling, 75 (2018) 38-69

Kabatek, J., van Soest, A., and Stancanelli, E. (2014). Income taxation, labour supply and housework: A discrete choice model for French couples. Labour Economics, 27(C):30-43.

Kaliskova (2014). Labor supply consequences of family taxation: Evidence from the Czech Republic. Labour Economics, Elsevier, vol. 30(C), pages 234-244.

Kornstad, T. and T. O. Thoresen, 2007. “A Discrete Choice Model for Labor Supply and Childcare", Journal of Population Economics 20.4 (2007): 781-803.

LaLumia, S. (2008). The effects of joint taxation of married couples on labor supply and nonwage income. Journal of Public Economics, 92(7):1698-1719.

Labega, M. Jose', Oliver X., and Spadaro A. (2008). Discrete choice models of labour supply, behavioural microsimulation and the Spanish tax reforms. The Journal of Economic Inequality, Springer;Society for the Study of Economic Inequality, vol. 6(3). 
Liegeois P, and Islam N. (2013). "Dealing with Negative Marginal Utilities in the Discrete Choice Modeling of Labor Supply”. Economics Letters, 2013, vol. 118, n 1, pp. 16-18.

Mehran, F. (1976). “Linear Measures of Inequality”. Econometrica 44, 805-809.

Selin, H. (2014). The rise in female employment and the role of tax incentives. An empirical analysis of the Swedish individual tax reform of 1971. International Tax and Public Finance, 21(5):894-922.

Sutherland, H. and Figari, F. (2013). EUROMOD: the European Union tax-benefit microsimulation model. International Journal of Microsimulation, 1(6):4-26.

Van Soest A. (1995). Structural Models of Family Labor Supply: A Discrete Choice Approach. Journal of Human Resources, 30, 63-88.

Van Soest, A., Das, M. (2001). Family labor supply and proposed tax reform in the Netherlands. De Economist 149: 191-218.

Vlasblom, J.D. (2001). Taxes, female labour supply and household income: differences between the Netherlands and the Federal Republic of Germany. Applied Economics, Volume $33(6)$

Yaari, M.E. (1988). “A controversial Proposal Concerning Inequality Measurement”. Journal of Economic Theory 44, 381-397. 


\section{Appendix}

Table A1. The estimated parameter of couple household labour supply model with 18 combinations PSELL 2010 (income year 2009).

\begin{tabular}{|c|c|c|}
\hline Variable & Coefficient & SE \\
\hline \multicolumn{3}{|c|}{ Observed Heterogeneity parameters } \\
\hline \multicolumn{3}{|l|}{ Husband's leisure: } \\
\hline Intercept & $-0.521 * *$ & 0.263 \\
\hline Big City & $0.406^{* * *}$ & 0.111 \\
\hline Primary school & $0.539 * * *$ & 0.116 \\
\hline Secondary school & 0.232 & 0.181 \\
\hline Age $18-30$ & $-3.648 * * *$ & 0.401 \\
\hline Age $31-40$ & $-2.974 * * *$ & 0.290 \\
\hline Age 41-50 & $-2.615 * * *$ & 0.245 \\
\hline Age 51-60 & $-2.022 * * *$ & 0.216 \\
\hline No. Children & $-0.244 * * *$ & 0.055 \\
\hline No. Child 0-5 & -0.039 & 0.108 \\
\hline \multicolumn{3}{|l|}{ Wife's leisure: } \\
\hline Intercept & $2.181 * * *$ & 0.581 \\
\hline Big City & -0.031 & 0.103 \\
\hline Primary school & $0.474 * * *$ & 0.126 \\
\hline Secondary school & $0.389 * * *$ & 0.147 \\
\hline Age $18-30$ & $-6.154 * * *$ & 1.024 \\
\hline Age $31-40$ & $-6.268 * * *$ & 1.019 \\
\hline Age 41-50 & $-5.796 * * *$ & 1.000 \\
\hline Age $51-60$ & $-4.591 * * *$ & 0.988 \\
\hline No. Children & $0.483 * * *$ & 0.066 \\
\hline No. Child 0-5 & $0.320 * * *$ & 0.090 \\
\hline \multicolumn{3}{|l|}{ Welfare: } \\
\hline Intercept & $6.619 * * *$ & 1.182 \\
\hline Big City & $-1.121 * * *$ & 0.269 \\
\hline Luxembourg born, Husband & $1.299 * * *$ & 0.346 \\
\hline Luxembourg born, Wife & 0.222 & 0.375 \\
\hline Primary school, Husband & $-0.601 * *$ & 0.276 \\
\hline Primary school, Wife & $-0.885 * * *$ & 0.293 \\
\hline Ageh 18-30,we & $-2.486 * *$ & 1.010 \\
\hline Ageh 31-40,we & $-1.761 *$ & 0.968 \\
\hline Agew 18-30,we & $-2.067 * *$ & 0.988 \\
\hline Agew 31-40,we & -1.495 & 0.971 \\
\hline No. Children & $-0.439 * * *$ & 0.129 \\
\hline No. Child 0-5 & 0.158 & 0.186 \\
\hline
\end{tabular}

Continue Table A1 ... 
Continue Table A1 ...

\begin{tabular}{|c|c|c|}
\hline Variable & Coefficient & SE \\
\hline \multicolumn{3}{|c|}{ Unobserved Heterogeneity parameter } \\
\hline \multicolumn{3}{|l|}{ Husband's leisure: } \\
\hline Mass Point1 & $-0.942 * * *$ & 0.0325 \\
\hline Mass Point2 & -0.223 & 0.263 \\
\hline Mass Point3 & $1.165 * * *$ & 0.322 \\
\hline \multicolumn{3}{|l|}{ Wife's leisure: } \\
\hline Mass Point1 & $2.2305 * * *$ & 0.0325 \\
\hline Mass Point2 & $3.198 * * *$ & 0.424 \\
\hline Mass Point 3 & $-5.428 * * *$ & 0.722 \\
\hline \multicolumn{3}{|l|}{ Welfare: } \\
\hline Mass Point1 & $2.419 * * *$ & 0.0325 \\
\hline Mass Point2 & $-2.496 * * *$ & 0.627 \\
\hline Mass Point3 & 0.077 & 1.508 \\
\hline \multicolumn{3}{|l|}{ Type probabilities: } \\
\hline & 0.696 & \\
\hline & 0.216 & \\
\hline & 0.088 & \\
\hline \multicolumn{3}{|l|}{ Utility parameters: } \\
\hline Income & 0.415 & 0.311 \\
\hline Income*Income & $0.406 * * *$ & 0.055 \\
\hline Leisure(Male)*Leisure(Male) & $0.574 * * *$ & 0.111 \\
\hline Leisure(Female)*Leisure(Female) & $1.124 * * *$ & 0.286 \\
\hline Income*Leisure(Male) & $0.717 * * *$ & 0.085 \\
\hline Income*Leisure(Female) & $0.558 * * *$ & 0.077 \\
\hline Leisure(Male)*Leisure(Female) & $1.024 * * *$ & 0.103 \\
\hline \multicolumn{3}{|l|}{ Fixed costs: } \\
\hline Male & $2.112 * * *$ & 0.174 \\
\hline Female & $-0.637 * * *$ & 0.228 \\
\hline Log-likelihood value: & 3719.4 & \\
\hline Number of observations & 2276 & \\
\hline
\end{tabular}

Note: We use the cross-sectional EU-SILC survey data of year 2010 (income year 2009) of 2276 couple household. Labour supply decision of partners in couple and social welfare participation decision of household have been estimated jointly.

$*, * *, * * *$ denote significance at the 10,5, and 1 percent levels, respectively.

Source: Own calculations using LuxTaxBen. 


